\title{
Subperichondrial haematomas of the nasal alar cartilage
}

\author{
Valentinos Sofokleous (1) , Konstantinos Papageorgiou, ${ }^{1}$ \\ Stavroula Alexandra Faliagka, ${ }^{1}$ Georgios Chrysovitsiotis (i) ${ }^{2}$
}

'Department of Pediatric Otorhinolaryngology, Athens Children's Hospital "P. \& A. Kyriakou", Athens, Attiki, Greece ${ }^{2}$ 1st Otorhinolaryngology Department, National and Kapodistrian University of Athens School of Medicine, Athens, Attiki, Greece

Correspondence to

Valentinos Sofokleous; sofokleousv@outlook.com

Accepted 23 December 2020

A Check for updates

(c) BMJ Publishing Group Limited 2021. No commercial re-use. See rights and permissions. Published by BMJ.

To cite: Sofokleous $\mathrm{V}$, Papageorgiou K, Faliagka SA, et al. BMJ Case Rep

2021:14:e240150.

doi:10.1136/bcr-2020-

240150

\section{DESCRIPTION}

Case 1: An 11-year-old boy presented to the casualty department complaining of pain over the tip of his nose and difficulty in nasal breathing following a fall on the ground that happened 2 days ago. He also reported a short-lasting, self-limited episode of epistaxis from his right nostril. Clinical examination revealed a reddish, fluctuant swelling that appeared to derive from the roof of the right nasal vestibule, without any septal or nasal bone lesions or deformity. An alar cartilage haematoma was suspected, and the patient was brought to the theatre (figure 1A,B). Under general anaesthesia, a marginal incision was performed, just at the caudal border of the alar cartilage, and the haematoma was thoroughly drained. A $3 \mathrm{~cm}$ rectangular piece of a sterile glove was inserted midway through the incision as a drain, and the vestibule was packed with an antibiotic-soaked gauze (figure 1C,D). The drain was removed on postoperative day 2 , and the packing one day later.

Case 2: A 3 year-old boy presented to the casualty department with a history of nasal injury following

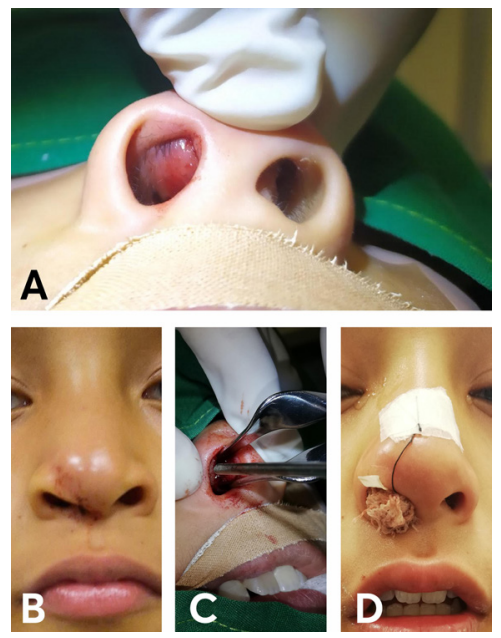

Figure 1 Photographs from case 1: (A) Intraoperative photograph from case one showing a reddish, fluctuant swelling that projects from the undersurface of the right major alar cartilage, blocking the entrance to the right nasal cavity. (B) Anteroposterior view demonstrating that the haematoma was not readily apparent from the exterior aspect of the nose. (C) A subperichondrial haematoma was drained through a marginal incision at the caudal border of the right major alar cartilage. (D) The right nasal vestibule was packed for 3 days with an antibiotic-soaked gauze. A rectangular piece from a sterile glove was used as a drain.
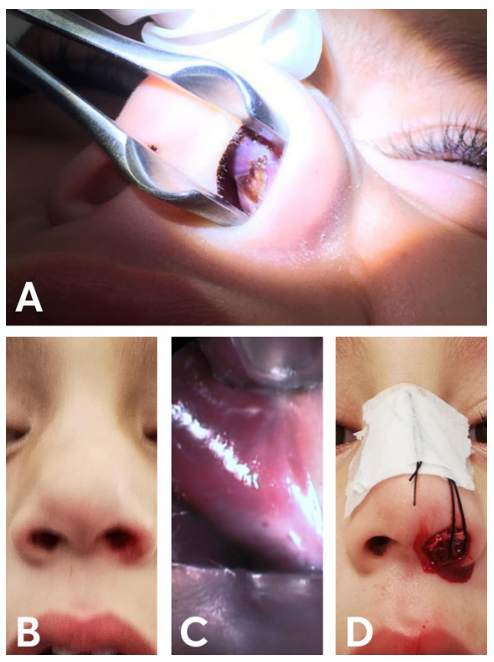

Figure 2 Photographs from case 2: (A) Anterior rhinoscopy revealed a blueish, fluctuant swelling at the roof and the lateral sidewall of the left nasal vestibule. (B) The haematoma was unnoticeable from the exterior aspect of the nose. Anterior rhinoscopy with careful inspection of the nasal vestibule is key to not missing these rare lesions (C) Intraoperative close-up view, just before the incision was made. (D) The left nasal vestibule was packed for 2 days with an antibiotic-soaked gauze.

a fall from his riding toy on the previous day. There was moderate swelling over his nasal bridge, and anterior rhinoscopy showed a fluctuant, blueish swelling just beneath the left alar cartilage area (figure 2A,B). The rest of the examination was otherwise unremarkable. Under general anaesthesia, an incision in the skin of the left vestibule was made that was deepened until the undersurface of the alar cartilage. The haematoma was evacuated, and the vestibule was packed with an antibiotic-soaked gauze for 2 days (figure 2C,D).

Both cases received postoperatively oral antibiotics for a week. Both had an uneventful recovery with no complications and no residual deformity.

A subperichondrial haematoma arises from the extravasation of blood beneath an intact perichondrium. Cartilage, being an avascular tissue, relies on the diffusion of oxygen and nutrients from the perichondrium capillaries for its survival. Accumulation of stagnant blood between perichondrium and cartilage disassembles this physiological unity and deprives the cartilage of adequate glucose and oxygen supply, leading, ultimately, to tissue necrosis and resorption and to subsequent deformity and loss of function. ${ }^{1}$ 
Although subperichondrial haematomas of the nasal septum comprise a well-recognised, relatively common and potentially dreadful consequence of mid-facial injuries, their counterparts in the region of the major alar cartilage are much rarer and unwonted. However, they may cause equally dire aftereffects, such as cosmetic deformities and compromised nasal breathing resulting from loss of support. ${ }^{1-3}$ Another primary concern of an unaddressed haematoma would be the grievous septic intracranial complications that may ensue from successive abscess formation. ${ }^{4}$

Only five cases of nasal alar cartilage haematomas have been reported in the literature so far, most of which concern a paediatric population. ${ }^{235}$ The patients of this report are also children. This may suggest that children may be more susceptible to the formation of alar haematomas after minor head injuries. This

\section{Learning points}

- As they are extremely rare and unwonted, these haematomas may go unnoticed if the clinician does not systematically inspect the vestibular side of the alar cartilages in every case of, even minor, midfacial trauma.

- If left untreated, consequences may be equally severe to nasal septal haematomas.

- Early diagnosis and prompt treatment are of paramount importance. Timely drainage of the haematoma, in all likelihood, spared our patients serious septic complications and prolonged cosmetic or dysfunctional deformities. assumption is in line with the remark of a heightened prevalence of septal haematomas in paediatric populations, presumably due to the structurally weaker cartilage and a loosely adherent mucoperichondrium. ${ }^{67}$

Contributors VS was the primary attending surgeon and wrote the first draft. KP $\mathrm{SAF}$ and $\mathrm{GC}$ reviewed and edited the draft and the images. All authors approved the final manuscript.

Funding The authors have not declared a specific grant for this research from any funding agency in the public, commercial or not-for-profit sectors.

Competing interests None declared.

Patient consent for publication Parental/guardian consent obtained.

Provenance and peer review Not commissioned; externally peer reviewed.

ORCID iDs

Valentinos Sofokleous http://orcid.org/0000-0001-8213-3197

Georgios Chrysovitsiotis http://orcid.org/0000-0001-6734-0542

\section{REFERENCES}

1 Olsen KD, Carpenter RJ, Kern EB. Nasal septal injury in children. diagnosis and management. Arch Otolaryngol 1980;106:317-20.

2 Meehan T, Kaddour H, Lannigan FJ. Alar cartilage haematoma. J Laryngol Otol 1994;108:500-2.

3 Green KM, Board T, Mason JD. Alar haematoma. J Laryngol Otol 1999;1 13:1104-5.

4 Alshaikh N, Lo S. Nasal septal abscess in children: from diagnosis to management and prevention. Int J Pediatr Otorhinolaryngol 2011;75:737-44.

5 Pham T V, Lannigan FJ. Haematoma of the alar cartilage. Aust J Otolaryngol 2001;4:127-8.

6 Wright RJ, Murakami CS, Ambro BT. Pediatric nasal injuries and management. Facial Plast Surg 2011;27:483-90.

7 Canty PA, Berkowitz RG. Hematoma and abscess of the nasal septum in children. Arch Otolaryngol Head Neck Surg 1996;122:1373-6.

Copyright 2021 BMJ Publishing Group. All rights reserved. For permission to reuse any of this content visit

https://www.bmj.com/company/products-services/rights-and-licensing/permissions/

BMJ Case Report Fellows may re-use this article for personal use and teaching without any further permission.

Become a Fellow of BMJ Case Reports today and you can:

- Submit as many cases as you like

- Enjoy fast sympathetic peer review and rapid publication of accepted articles

- Access all the published articles

- Re-use any of the published material for personal use and teaching without further permission

\section{Customer Service}

If you have any further queries about your subscription, please contact our customer services team on +44 (0) 2071111105 or via email at support@bmj.com.

Visit casereports.bmj.com for more articles like this and to become a Fellow 